\title{
WHITE-TAILED DEER NEAR FORT SMITH, N.W.T.
}

\author{
by E. Kuyt, Canadian Wildlife Service, Fort Smith
}

Deer in the Northwest Territories have been reported occurring near Fort Liard and South Nahanni on the Liard River, near the west end of Great Slave Lake and as far north as Fort Simpson and Wrigley on the Mackenzie River (Summary report by D. R. Flook, Canadian Wildlife Service files, January 15, 1965). Without exception, the various reporters have indicated that deer were rare and that the species involved was the Mule Deer. It is most likely that near the northern limit of their range, the deer population fluctuates greatly, depending upon the vagaries of the northern climate.

Hall and Kelson in The Mammals of North America (1959, Vol. II, p. 1005) include Fort Simpson and the west end of Great Slave Lake in the northern part of the Mule Deer's range. By contrast, the range of the White-tailed Deer in North America is shown to extend northward only to an east-west line through Canada at about the latitude of Edmonton (Hall and Kelson, op. cit., p. 1009).

In view of the approximate northern range limit of the White-tailed Deer as given by Hall and Kelson, it is of interest to record several reports of White-tailed Deer that have come to my attention:

1. On September 13, 1965, Constable Glen Wood of the R.C.M.P., Forth Smith Detachment, informed me that he had seen a White-tailed Deer near Salt River about 12 miles south of Fort Smith. At that place, the Salt River forms the northeast boundary of Wood Buffalo National Park.

2. That same fall and just after the first frost, my wife and I observed tracks of a herd of five deer in frozen mud along the road at a point about five miles southwest of Bell Rock, N.W.T. The tracks were seen north of the Alberta boundary and were seen independently by another resi- dent of Fort Smith. The five animals had been walking and I was unable to determine whether the tracks were those of Mule Deer or White-tailed Deer.

3. Finally, on August 28, 1966, my wife and I, while driving along the same road and about eight miles west of Bell Rock, N.W.T., saw a Whitetailed doe jump across the road. Both of us have seen numerous Whitetailed Deer in Saskatchewan and the present observation was made during daylight hours and at a range of less than 40 yards. The doe showed the typical reddish brown coat and was in good flesh. An examination of the area failed to show any other deer tracks.

Wardens of Wood Buffalo National Park have told me that White-tailed Deer are sometimes seen west of Peace Point. The observations of White-tailed Deer reported here were made approximately 400 miles north of the northern range of this species as given in The Mammals of North America by Hall and Kelson.

\section{GRIZZLY BEAR SKULL FROM ONTARIO}

In 1964 as reported by $R$. L. Peterson (Nature, 208:1233, 1965) a Grizzly Bear skull in excellent preservation was found near Lake Simcoe, Ontario. The skull was $11,700 \pm 250$ years old. W. M. Tovell and R. E. Deane of the Royal Ontario Museum (Science, 154:158, 1966) visited the site and explain that the gravel pit in which the skull was found is lower than the water level of glacial Lake Algonquin. The gravel deposit was built on an island or headland and deposition was extremely rapid which explains the excellent preservation of this Grizzly Bear skull. 